\title{
A Correlational Study on Habit in Watching English Movie, Self-Efficacy, and Writing Skill
}

\author{
Samsu Widya Resti, Siswantoro, Teguh Sarosa \\ English Education Department \\ Teacher Training and Education Faculty \\ Sebelas Maret University of Surakarta
}

\author{
Email: samsuwidyaresty@gmail.com
}

\begin{abstract}
This research aims to find correlation between (1) habit in watching English movie and writing skill; (2) self-efficacy and writing skill; and (3) habit in watching English movie, and self-efficacy toward writing skill simultaneously. The study was carried out at SMK in Wonoasri. The sample of the study is 22 students out of 260 students in tenth grade as the population. The instruments used for collecting data of habit in watching English movie and selfefficacy is questionnaire, while writing test was used for collecting the data of writing skill. The techniques to analyze data are single and multiple regression correlation. The result of analysis shows that there is a positive correlation between (1) habit in watching English movie and writing skill; (2) self-efficacy and writing skill; and (3) habit in watching English movie, self-efficacy simultaneously and writing skill. The positive correlation indicates that the increase of habit in watching English movie and self-efficacy is followed by the increase of studente's writing skill at the same time.
\end{abstract}

Keywords: correlation, habit in watching English movie, self-efficacy, writing skill

\section{INTRODUCTION}

English plays an important role for human life in many countries and no exception in Indonesia. Indonesian government put English in school as a subject whether in elementary, junior high to senior high schools even in kindergarten. Some people usually prefer to master in speaking or reading skill only but we know that writing skill can not be omitted. Writing is a difficult activity for most people. Writing can be said to be the act of forming graphic symbols e.g. letters or combination of letters: making marks on a flat surface. But writing is clearly much more than the production of graphic symbols, just as speech is more than the production of sounds (Byrne, 1997: 1).

As an important skill in daily life, writing should make people get used to learn. Many people write for reasons unrelated to their work: letters, diaries, messages, shopping list, budgets, etc. When we are continuing our study to the higher level or when we will apply for a job, writing is indispensable. For examples in a job application letter we should use suitable diction to convey the correct messages.

It is not easy to determine the range of writing that should be developing in schools. However, traditional forms, such as the essay, are not normally practiced in 
society. There is a danger in developing forms that are only school-specific, but something that more important in teaching writing is developing an understanding of how texts are organized (Harris, 1993: 44).

There are several steps in writing process Segal and Pavlik explain step to write in their book A Writing Process Book (1997), as follows: (1) Exploring Ideas, (2) Organizing Ideas, Developing cohesion and style, (4) Writing the first draft, (5) Editing Practice, (6) Editing your writing, (7) Writing the second draft.

Writing also has purpose and the purpose will influence kind of language that they choose and also how to use the language. There are four major purposes of writing, as follows: (1) To express feeling, (2) To provide information, (3) To persuade, and (4) To literary work.

From the explanations above, it can be concluded in simple way that writing is the skill in process of gathering and ordering ideas from information or experiences, then forming it into visible letters which have conventional manner including correct grammar, vocabulary choice, organization of ideas, and mechanics which include: spelling,

punctuation, capitalization and paragraphing.

Many factors can influence students $^{\text {ee }}$ education, and included their writing skill. Educational psychologists spend their time studying ways to describe and improve learning and teaching. Glover and Ronning in Elliot (2000: 2) suggested that educational psychology includes topics that span human development, individual differences, measurement, learning, and motivation and is both a data-driven and a theory driven discipline. We know that people ${ }^{e e}$ psychology is always being a factor in people $\mathrm{s}$ performances or actions; and one of the psychological factors is self-efficacy.

In writing, the Psychological factors will affect the people ${ }^{\text {ee }}$ ability in producing good writing. Self-confidence will affect people to be free or not in expressing written idea. Although the idea expressed in written text, we know that writing also need a courage to write from the first sentence, next sentence, to final. Self-efficacy refers to "the belief that one can successfully execute a given behavior" (Phares, 1984:376). According to Bandura (1994: 1), self-efficacy is "people "e beliefs about their capabilities to produce designated levels of performance that exercise influence over events that affect their lives".

Self-efficacy will be influence people to be confident in writing. Good writing is known where the product of written text uses suitable vocabulary, suitable diction, and also it has good idea in developing writing. There is differentiate of self-efficacy of people, there are people who have high selfefficacy and the other is low self-efficacy. there are some dimensions of self-efficacy that can be an indicator to measure one $\mathrm{s}$ self-efficacy. Those three dimensions are magnitude, generality, and strength (Bandura: 1994).

Self-efficacy have sources from many aspects. According to Bandura (1994), the sources of self-efficacy are as follows: (1) Mastery experience, (2)

Vicarious experience, (3) Social persuasion, and (4) Psychological arousal. Those sources can bring various effects for each people. Self-efficacy takes an important role in language learning. It is because self-efficacy contains what students can do with their knowledge or 
ability. In language learning, students need to be persistent to be able in four language skills, namely listening, speaking, reading, and writing.

The students who have high selfefficacy will put their effort, motivation and interest to master language skills and those who have high self-efficacy will not easily give up in learning language even when they meet difficulties; they just keep persistence to face them. Based on the explanation above, it can be concluded that high self-efficacy is needed for learners in language learning. It is because when they have high self-efficacy they will set their goal and manage difficulties that they face in mastering four language skills.

Another aspect that can influence people in writing comes from some people ${ }^{e e}$ sabit which related to English, such as habit in listening English songs, playing games, reading novel in English, and also habit to watching English movies. Habits are behaviors pattern acquired by frequent repetition or physiological exposure that shows itself in regularity or increases facility of performance. The current habit little or much will influences of vocabulary use or vocabulary mastery so the writing will use various vocabulary. Good writing can be automatically mastered by studying material which is given by real example of the use of English. One of the example of materials that can be used is from English movies. This material is really authentic because in English movies will show how English is used to communicate.

David Brodwell and Kristin Thompson (1997: 3) note that film is motion picture in which the images are presented for us in illusory motion. The series of images of film must be displayed in rapid succession. By watching English movies, people either directly or not will learn many vocabularies. People will learn how to pronounce, accent, the meaning, and how to write the words. Movie is very entertaining for almost many people. Movie has a different level in the provision of information; it is stimulating interest through both words and pictures.

Movies or films are made differently based on their specific purposes. Heru Effendy (2009: 3- 6)

classified film as follows:

Documentary Films, (2) Short Films, (3) Feature-Length Films, and (4) Other Films.

Based on Effective Adult Learning (2014: 13), it is explained how far we tend to remember our level of involvement; They are $10 \%$ of what we read, $20 \%$ of what we hear, $30 \%$ of what we see, $50 \%$ of what we hear and see, $70 \%$ of what we say, $90 \%$ of what we say and do. It shows that movie has good effect to the language learner.

Besides from books and music, English movies can be effective for learning English. It will be more, movie consists of images and sounds, theme and story, and the theme come from social environment such as: social phenomena, social interest, and cultural value (Allen and Gomery, 1993: 158). In other words, Allen and Gomery add that film is an open system. It is not just a set of components forming a whole, but an interrelated set of components that condition and are conditioned by each other. In learning language, movie has power because it is composed of moving image as a means of symbolic expression and movie also as a language which is composed of signs and symbols (Douglass and Harnden, 1996: 250). 
From the definitions above, it can be simply said that movie, or commonly called as film, is motion picture which telling a story and presented in moving images.

Based on explanations above, it can be concluded that people $\mathrm{s}$ habit in watching movies especially English movie can be defined as activity which is done regularly. People do this activity without thinking about many aspects but only watching automatically. This habit can bring some effect which can be gradually perceived and occur subconsciously. So this is can be said that habit watching English movie is indicated by repetition, automatically, interest, and effect.

The hypotheses of the research can be formulated as follows: (1) there is positive correlation between students ${ }^{\text {ee }}$ habit in watching English movie and writing skill; (2) there is positive correlation between self-efficacy and writing skill; and (3) there is positive correlation between students ${ }^{\text {ee }}$ habit in watching English movie, self-efficacy simultaneously, and writing skill.

Based on the rationale above, the aims of the study are to determine the correlation between (1) habit in watching English movie and writing skill; (2) selfefficacy and writing skill; and (3) habit in watching English movie, self-efficacy, and writing skill. This study used correlational study.

\section{RESEARCH METHODS}

The research is carry out at the tenth grade of SMK in Wonoasri Madiun, East Java. The sample of this research is 22 students. Related to the objectives of the study, the method used in this study is correlational study. Fraenkel and Wallen (2000: 359) state, "Correlation research is a research which is done to determine the relationship among two or more variables, and to explore their implications for cause and effect". The writer uses this method because she want to know the level of correlation between habit in watching English movie, selfefficacy, and writing skill. There are three possible results of a correlation study: a positive correlation, a negative correlation, and no correlation.

In this research there are two kinds of variables, namely independent variable and dependent variable. The independent variables are habit in watching English movie and self-efficacy; while the dependent variable is writing skill.

The researcher uses questionnaire and test as the techniques to collect the data of the study. According to Halonen and Santrock (1999: 19) questionnaire is similar to structured interview except that the respondents read the questions and mark their answers on paper or some other medium rather than verbally responding to the interviewer.

Arikunto (2006: 152) states that questionnaire is divided into two types; closed and opened questionnaire. Closed questionnaire is questionnaire which the respondents only choose the available answer or responses, while, opened questionnaire is questionnaire which gives opportunity to the respondents to answer or response it by using their own words.

In this research, the questionnaire is used to measure the students ${ }^{\text {ee }}$ habit in watching English movie which consisted of 40 items in the try-out test and 33 items in the test. The writer uses the closedended questions, where the participant must select answer from the predetermined categories provided by the writer by filling 
the available column based from their own opinion.

In this research, the researcher uses closed questionnaire. This questionnaire is used to get the data whether the students have a high habit in watching English movies or low and also to get the data whether the students have high selfefficacy or low self-efficacy. It consists of 40 items which measure magnitude, generality, and strength. The items are followed by four provided answers and the students must answer the items given by giving a check in the column of the answer.

The scoring of the questionnaire is based on the Likert Scale Type. Besides questionnaire, test of writing skill is used to collect the data about the studentse writing skill. Brown (2004: 3) defines test is a method of measuring a person ${ }^{\text {ee }} \mathrm{s}$ ability, knowledge, or performance in a given domain. In this research, test is used as a systematic procedure to observe and measure students ${ }^{\text {ee }}$ writing skill.

Writing test is an essay test in the form of paragraph writing test. In this research, students will ask to choose one available topics then they have to develop the topic into good paragraphs by considering the content, organization, vocabulary, language use, and mechanism.

There are five general categories which are often the basis for the evaluation of the students "e writing skill, including content, organization, vocabulary, language use or grammar, and mechanism. To score writing skill, the writer uses scoring rubric of writing and it is explained by Jacobs (in Reid, 1993: 236237).

In analyzing the data, the researcher tested the three hypotheses of the study. Product Moment Formula is used to test the first and the second hypotheses which say that there is a positive correlation between habit in watching English movie and writing skill, and there is a positive correlation between self-efficacy and writing skill. Besides, to know whether the coefficient correlation between $\mathrm{X}$ and $\mathrm{Y}$ is significant or not, the researcher uses $t$ test formula. The correlation coefficient is significant if the value of $t$ observation $\left(t_{0}\right)$ is higher than $t$ table $\left(\mathrm{t}_{\mathrm{t}}\right)$, or $\mathrm{t}_{\mathrm{O}}>\mathrm{t} \mathrm{t}$.

Multiple Linear Correlation is used to test the third hypothesis which says that there is a positive correlation between habit in watching English movie, selfefficacy simultaneously, and writing skill. Besides, to find out whether or not the coefficient of Ry $(1,2)$ is significant, the researcher uses $\mathrm{F}$ test formula. The correlation coefficient is significant if the value of $\mathrm{F}$ observation $\left(\mathrm{F}_{\mathrm{O}}\right)$ is higher than $\mathrm{F}$ table $\left(\mathrm{F}_{\mathrm{t}}\right)$, or $\mathrm{F}_{\mathrm{O}}>\mathrm{F}_{\mathrm{t}}$.

\section{RESEARCH FINDINGS AND DISCUSSIONS}

The data of habit in watching English movie and self-efficacy are collected by using questionnaire. From the questionnaire, it is obtained that the highest score of habit in watching English movie is 129 and the lowest score is 69 , so the range is 60 . The mean of the average score is 109 , the mode is 84.64 and the median is 112.3 . The standard deviation is 15.25

While, the data of self-efficacy the highest score 135 and the lowest score is 94 , so the range is 41 . The mean or the average score is 112 . The mode is 103 and the median is 108.5. The standard deviation is 12.34 .

The last is the data of writing skill which are collected by using test. It is 
obtained that the highest score 86 and the lowest score is 59 , so the range is 27 . The mean or the average score is 77 . The mode is 79.75 and the median is 77.88 . The standard deviation is 6.23 .

The researcher uses Pearson Product Moment Formula to test the first hypothesis. In the first hypothesis says that there is a positive correlation between habit in watching English movie $\left(\mathrm{X}_{1}\right)$ and writing skill (Y). The correlation analysis shows that the correlation coefficient $\left(\mathrm{r}_{\mathrm{x}} \mathrm{y}\right)$ between habit in watching English movie (X1) and writing skill ( $\mathrm{Y}$ ) is 0.14807 . After being calculated on the basis of the $t$-value, the value of $t_{0}$ ( $t$ obtained) is 1.8644 . The value of $t_{t}(t$ table) at the level of significance $\alpha=$ 0.05 for $\mathrm{n}=22$ is 1.72 . Because to (1.8644) $>\mathrm{tt}$ (1.72), it can be concluded that the coefficient correlation is significant. It means that $\mathrm{H}_{\mathrm{O}}$ is rejected. So, there is a positive correlation between habit in watching English movie $\left(\mathrm{X}_{1}\right)$ and writing skill (Y). The coefficient of determination between $\mathrm{X}_{1}$ and $\mathrm{Y}$ is 0.14807 . It means that $14.80 \%$ variance of writing skill is determined by the students ${ }^{\text {ee }}$ habit in watching English movie and $85.20 \%$ variance of writing skill is determined by other factors.

The second hypothesis in this research is that there is a positive correlation between self-efficacy (X2) and writing skill (Y). To test the hypothesis, the researcher analyzes the collected data by using Pearson Product Moment Formula. The correlation analysis shows that the correlation coefficient $\left(r_{x} 2 y\right)$ between self-efficacy $\left(\mathrm{X}_{2}\right)$ and writing skill (Y) is 0.3042. After being calculated on the basis of the t-value, the value of $t_{0}$ ( $\mathrm{t}$ obtained) is 2.9567. The value of $\mathrm{tt}(\mathrm{t}$ table) at the level of significance $\alpha=0.05$ for $n=22$ is 1.72 . Because $t_{0}(2.9567)>t_{t}$
(1.72), it can be inferred that the coefficient correlation is significant. It means that $\mathrm{H}_{\mathrm{O}}$ is rejected. So, there is a positive correlation between self-efficacy $\left(\mathrm{X}_{2}\right)$ and writing skill $(\mathrm{Y})$. The coefficient of determination between $\mathrm{X}_{2}$ and $\mathrm{Y}$ is 0.3042 . It means that $30.42 \%$ variance of writing skill is determined by students ${ }^{\text {ee }}$ self-efficacy and $69.58 \%$ variance of writing skill is determined by other factors.

In the third hypothesis, the researcher analyzes the collected data by using the Multiple Linear Regression Formula. This hypothesis says that there is a positive correlation between habit in watching English movie (X1), SelfEfficacy (X2) and Writing Skill (Y). The multiple linear regression analysis shows that the coefficients of $\mathrm{a}_{1}, \mathrm{a}_{2}$ and $\mathrm{a}_{0}$ are $0.2162,0.4172$, and 7.246. Therefore, the multiple linear regression equation of $\mathrm{Y}$ on $\mathrm{X}_{1}$ and $\mathrm{X}_{2}$ becomes $\hat{\mathrm{Y}}=7.2458+0,2162$ $\mathrm{X}_{1}+0,4172 \mathrm{X}_{2}$. The value of $\mathrm{F}_{\mathrm{O}}$ is 77.604 and the distribution table $\left(\mathrm{Ft}_{\mathrm{t}}\right)$ with the degree of freedom (df) 2 and 20 at the level of significance $\alpha=0.05$ is 3.49 . It is obvious that $\mathrm{F}_{\mathrm{O}}>\mathrm{F}_{\mathrm{t}}$; it means that the regression of $\mathrm{X}_{1}, \mathrm{X}_{2}$, and $\mathrm{Y}$ is significant.

The multiple correlation analysis shows that the correlation coefficient $\left(\mathrm{R}_{\mathrm{x} 1 \mathrm{x} 2 \mathrm{y}}\right)$ between Habit in Watching English Movie (X1), Self-Efficacy $\left(\mathrm{X}_{2}\right)$ and Writing Skill (Y) is 0.8858 After being calculated to the F-value, the value of Fo ( $\mathrm{F}$ obtained) is 195.81. The value of $\mathrm{F}_{t}$ at the level of significance $\alpha=0.05$ and $\mathrm{df}$ (degree of freedom) 2:20 for $\mathrm{N}=22$ is 3.49. Because $F_{O}(195.81)$ is higher than $F_{t}$ (3.49), the coefficient correlation is significant. It means that $\mathrm{H}_{\mathrm{O}}$ is rejected. So, there is a positive correlation between Habit in Watching English Movie (X1), Self-Efficacy $\left(\mathrm{X}_{2}\right)$ simultaneously and Writing Skill (Y). $\mathrm{R}^{2}$ (coefficient 
determination) is 0.8858 . It means that $88.58 \%$ variance of writing skill is determined by the habit in watching English movie $\left(\mathrm{X}_{1}\right)$ and self-efficacy $\left(\mathrm{X}_{2}\right)$ and $11.42 \%$ variance of writing skill is determined by other factors.

The result of the correlation analysis between two independent variables (habit in watching English movie and self-efficacy) and one dependent variable (writing skill) is positive and significant. The correlation between habit in watching English movie, self-efficacy, and writing skill can be illustrated as follows:

Writing is a difficult activity for most people. In writing someone will be influenced by many factors especially psychological factor. The Psychological factors will affect the people $e^{\text {ee }}$ ability in producing good writing. Self-confidence will affect people to be free or not in express written idea. Although the idea expressed in written text, we know that writing also need a courage to write from the first sentence, next sentence, to final.

The internal psychological factor itself such as: interest, motivation, selfconcept, and anxiety. One of psychological factor that can influence writing skill is self-efficacy. Self-efficacy refers to "the belief that one can successfully execute a given behavior" (Phares, 1984:376). According to Bandura (1994: 1), selfefficacy is "people $\mathrm{ec}$ beliefs about their capabilities to produce designated levels of performance that exercise influence over events that affect their lives".

Self-efficacy will be influence people to confident in writing. Good writing is known where the product of written text is use suitable vocabulary, suitable diction, and also have good idea in developing writing. There is differentiate of self-efficacy of people, there are people who have high self-efficacy and the other is low self-efficacy.

Another aspect that can influence people in writing is come from some people ${ }^{e e}$ habit that related English, such as habit in listening English songs, playing games, reading novel in English, and also habit to watching English movies. The current habit little or much will influence of vocabulary use or vocabulary mastery so the writing will use various vocabulary. Good writing of people can be automatically by study from material which is given by real example of the use of English. One of the example of materials that can be used is from English movies. This material is really authentic material because in English movies will show how English language is used to communicate.

By watching English movies, people either directly or not will learn many vocabularies. People will learn how to pronounce, accent, the meaning, and how to write the words. Movie is very entertaining for almost many people. Movie has a different level in the provision of information; it is stimulating interest through both words and pictures. Based on Effective Adult Learning (2014: 13) it is describes how we tend to remember our level of involvement? They are 10\% of what we read, $20 \%$ of what we hear, $30 \%$ of what we see, $50 \%$ of what we hear and see, $70 \%$ of what we say, $90 \%$ of what we say and do. It shows that movie has good effect to the language learner.

Besides from books and music, English movies can be effective for learning English. It will be more, movie consists of images and sounds, theme and story, and the theme come from social environment such as: social phenomena, 
social interest, and cultural value (Allen and Gomery, 1993: 158).

Based on the finding, it is clear that the habit in watching English movie and self-efficacy simultaneously build a good relationship and give contribution toward studentse ${ }^{e e}$ writing skill.

\section{CONCLUSION AND SUGGESTION}

According to the research finding, the researcher finds out that habit in watching English movie and self-efficacy have contribution in student's writing skill; it is $88.58 \%$. It means that habit in watching English movie and self-efficacy cannot be ignored in the effort of improving students ${ }^{\text {ee }}$ writing skill.

Mastering vocabulary is a first

effort in learning language to communication. Wide range of vocabulary will make students able to deliver their idea and able to create a good communication in English. Learning vocabulary can be get from many aspects, especially in this research is habit in watching English movie can be the one. High habit in watching English movie, little or much will give effect to the students to master vocabulary. Besides movie provides enjoyable classroom, it also provides meaningful context for vocabulary. When watching English movie, the students will get new vocabulary which are used in that movie unconsciously. More vocabulary has been mastered will make the students deliver their idea in written text easily. Besides that, only mastering vocabulary is not enough; a language teacher has to teach and encourage students how to write the word, how to use them in suitable context, and also how to put them in correct grammar so students will not make a mistake in using vocabulary to deliver their idea especially in written context.

Another factor that influences the students ${ }^{\text {ee }}$ writing skill is self-efficacy. This factor cannot be omitted because this student ${ }^{\text {ee }}$ sense of ability and knowledge (self-efficacy) will affect their confident, action, motivation, and then will influence their achievement in writing English. Students who have high self-efficacy and realize how far they are able to go with their knowledge and skill, they will do their best to improve their writing skill and have motivation to put out their effort to settle their anxiety of making mistake in writing English. Even, when they are asked to do a task that they never face before, for example joining English scientific work, making a play in English, even making an English novel, they will have a confidence to join it and put their best effort to achieve the best result too. The failure which is faced or the failure that they have before will not affect them to keep going; they will be persistent.

In conclussion, based in the results obatined from the research, it is recommended that habit in watching English movie and self-efficacy should be underlined especially by the teachers since they have great influence on writing skill. Consequently, the utilization of habit in watching English movie and self-efficay appropriatly will give benefit to the students not only in participating writing class but also in dealing with the communication and requirement in real lives.

Based on the conclusion and implication above, the researcher would like to give some suggestions to the teachers as follows: (1) The teacher should encourage the students to write, for example; ask the students to make a 
written text about something which interest or their experience; (2) The teacher should help the students facing and overcoming the problem which is faced by the students in writing English

(vocabulary, spelling, punctuation, grammar); (3) The teacher should vary the activity that promote writing, so that the students will not get bored and feel interested to write English. Teacher may use picture description, political issue, film review, make a poem, a simple play, etc;

(4) The teacher may give suggestions to the students on how to write English well and give some tips on overcoming their anxiety and worry when they want to write in English; (5) The teacher had better gives praise to every little thing which is done well by the students can be an effective way to raise their self-efficacy.

For the students, the researcher gives some suggestions as follows: (1) The

\section{BIBLIOGRAPHY}

Allen, R.C. and Gomery, D. (1993). Film History: Theory and practice. New York: Mc Graw-Hill, Inc.

Arikunto, Suharsimi. (2006). Dasar dasar penelitian pendidikan. Jakarta: Bumi Aksara.

Bandura, A. (1994). Encyclopedia of human behavior. Retrieved from: https://www.uky.edu/ eushe2/Band ura/BanEncy.html

Brodwell, D. \& Thompson, K. (1997).

Film art: an introduction volume 3. Mcgraw-Hill Company Inc.

Brown, H. Douglas. (2004). Language assessment: principles and classroom practice. San Fransisco State: Longman students should realize that writing skill is very important in mastering English; (2) The students should be more creative to improve their skill in writing by watching English movie until it becomes a habit for them; (3) The students should control their anxiety of making mistake when they write English; (4) The students should encourage themselves to more practice in writing English.

Since the research still has a lack of many things and far from being perfect, the researcher realizes that there are still many factors that influence the students ${ }^{\text {ce }}$ writing skill and which needs investigation. The researcher expects that there will be other researchers who will investigate the other factors relating to writing skill. The researcher also hopes that this research will be useful and can be used as a reference to others who will conduct and develop a similar study.

Byrne, Donn. (1997). Teaching writing skill. Essex: Longman Ltd.

Douglass, J.S., \& Harnden, G.P. (1996). The art of technique: an aesthetic approach to films and video production. A Simon \& Schuster Company.

Effective Adult Learning. (2012). University of Washington. Retrieved from https://humanservices.ucdavis.edu/ sites/default/files/Adult-EducationToolkit_Updated_022814.pdfElliot , S. et. al. (2000). Educational psychology: effective teaching, effective learning $3^{\text {rd }}$ edition. USA: McGraw-Hill Companies, Inc. 
Effendi, H. (2009). Mari membuat film: panduan menjadi produser. Jakarta: Erlangga.

Elliot, S. et. al. (2000). Educational psychology: effective teaching, effective learning $3^{\text {rd }}$ edition. USA: McGraw-Hill Companies, Inc.

Four major purposes of writing. Retrieved from http://blog.writeathome.com/index. php/2012/02/writing-modes-thefour-purposes-of-writing.

Fraenkel, Jack R., \& Wallen, Norman E. (2000). How to design and evaluate
Harris, John. (1993). Introducing writing. London: Penguin English.

Hallonen, J.S., \& Santrock, J. W. (1999). Psychology: contexts and application, $3^{r d}$. Boston: McGraw-Hill College.

Phares, E. Jerry. (1984). Introduction to personality. Ohio: Charles E. Merril Publishing Company.

Reid, J.M. (1993). Teaching ESL writing. New Jersey: A Paramount Communiations Company.

Segal, M.K. \& Pavlik, C. (1997). A writing process book. Mcgraw-hill international editions. The McGraw-Hill Companies, Inc. 